\title{
ПРАВА И ПОЛНОМОЧИЯ ИНОСТРАННЫХ АДВОКАТОВ В РФ: ПРОБЛЕМНЫЕ АСПЕКТЫ
}

\section{RIGHTS AND POWERS OF FOREIGN LAWYERS IN THE RUSSIAN FEDERATION: PROBLEMATIC ASPECTS}

\section{O. Ryabova \\ N. Kuznetsova}

Summary. This paper is devoted to the analysis of the rights and powers of foreign lawyers in Russia. The authors point to legislative gaps in this issue. Most of the permits and prohibitions in this area are contained in the explanations of the FPA and the Supreme Court of the Russian Federation, which in turn cannot qualitatively build relations between the Russian legal system and representatives of foreign lawyers. The authors point to the imperfection of legislation in this area, which, in turn, leads to misunderstandings both at the level of foreign lawyers and at the level of Russian law enforcement officers. The paper suggests ways to solve this problem thanks to an integrated approach that contains the experience of foreign countries and competent legislative regulation.

Keywords: legal profession, foreign lawyer, rights and powers, protection of rights and interests.

\author{
Рябова Ольга Алексеевна \\ Преподаватель, ФКОУ ВО «Владимирский \\ юридический институт ФСИН России» \\ frau.lelya2012@yandex.ru \\ Кузнецова Наталья Владимировна \\ Старший преподаватель, ФКОУ ВО «Владимирский \\ юридический институт ФСИН России» \\ kuznezova-1963@mail.ru
}

Аннотация. Настоящая работа посвящена анализу прав и полномочий иностранных адвокатов на территории России. Авторы указывают на законодательные пробелы В этом вопросе. Большинство разрешений и запретов в указанной сфере содержится в разъяснениях ФПА и ВС РФ, что в свою очередь не может качественно выстроить взаимоотношения российской правовой системы и представителей иностранной адвокатуры. Законодательное несовершенство в этой сфере, ведет к возникновению непонимания как на уровне иностранных адвокатов, так и на уровне российских правоприменителей. В работе предлагаются пути решения данной проблемы благодаря комплексному подходу, содержащему опыт иностранных государств и грамотное законодательное регулирование.

Ключевые слова: адвокатура, иностранный адвокат, права и полномочия, защита прав и интересов.

ского сообщества и может оказывать профессиональную юридическую помощь указанным в законе лицам.

А вот какие права имеет иностранный адвокат в системе российского правосудия и осуществления правовой помощи законодателем регламентировано очень ограниченно.

Федеральным законом «Об адвокатуре и адвокатской деятельности» (далее Закон об адвокатуре) предусмотрено, что адвокаты иностранных государств имеют возможность осуществлять правовую помощь своим подопечным по вопросам права своей страны. При этом осуществлять указанную деятельность они имеют право только после регистрации в специальном реестре федеральным органом исполнительной власти в области юстиции.[3] Также закон содержит указание на то, что иностранные адвокаты не могут быть допущены к осуществлению своей профессиональной деятельности по делам, содержащим информацию, имеющую отношение к государственной тайне. Иные законодательные акты, в том числе процессуальные, не содержат других указаний на объем прав иностранных адвокатов в судебном процессе на территории России. 
Безусловно, имеющейся в законе информации недостаточно, чтобы очертить круг прав и полномочий иностранных адвокатов на территории России.

Уточнения, восполняющие нехватку законодательной регламентации прав и полномочий иностранных адвокатов в РФ, содержатся в разъяснениях Федеральной Палаты Адвокатов (далее ФПА РФ) и Верховного Суда РФ. Однако в том виде, в котором сейчас находится правовая основа и тот объем полномочий, предоставляемых иностранным адвокатам, правовая система страны и защита прав и свобод граждан, иностранных граждан и лиц без гражданства не могут считаться достойными.

Мы полагаем, что правовое положение иностранных адвокатов в РФ не урегулировано должным образом и не дает им таких прав, которые не ограничивали бы их в осуществлении своей профессиональной деятельности. В России не найдены подходы к цивилизованному и грамотному предоставлению прав и полномочий представителям иностранных адвокатских сообществ, несмотря на то что были сделаны некоторые послабления на уровне ФПА РФ.

Так, в 2011 году ФПА РФ были отменены разъяснения, утвержденные Советом ФПА от 22.04.2004 (Протокол №5), которые ограничивали адвокатов иностранных государств в получении права пользоваться всеми правами и полномочиями, которые принадлежат российским адвокатам. Теперь, при прохождении определенной процедуры проверки компетентности, иностранные адвокаты смогут осуществлять свои профессиональные возможности на территории РФ. Таким образом, чтобы иметь возможность пользоваться всеми правами и полномочиями, предоставленными российским законодательством представителям адвокатского сообщества, иностранному адвокату, по сути, необходимо получить статус адвоката в соответствии с законодательством РФ. Эта позиция подтверждается и Верховным судом РФ, который признал в своем определении участие иностранного адвоката в качестве защитника по уголовному делу нарушением права на защиту иностранного гражданина, так как представлявший интересы данного гражданина иностранный адвокат не получал статуса адвоката в соответствии с действующим Федеральным законом «Об адвокатуре и адвокатской деятельности», а следовательно, не мог участвовать в судебном заседании.[4]

Таким образом, исходя из толкования имеющихся разъяснений, можно сделать вывод, что осуществлять свою профессиональную деятельность в полной мере на территории России, пользуясь правами и полномочиями, предусмотренными российским законодательством об адвокатуре, иностранные адвокаты могут, лишь подтвердив свою компетенцию, а фактически, пройдя процедуру получения статуса адвоката в соответствии с действующим Законом об адвокатуре. Однако, данные утверждения никак не закреплены законодательно, что, вызывает сомнение в абсолютности их дальнейшей реализации, так как сослаться при отстаивании своих прав можно на законом установленное разрешение, а учитывая, что прецедентное право не относится к источникам права в правовой системе нашего государства, разъяснения даже Верховного Суда РФ могут получить другой смысл вынесенным новым судебным актом.

Следует обратить внимание, что законодатель, ограничивая право иностранных адвокатов на осуществление адвокатской деятельности на территории РФ, одновременно п.п. 8 п. 2 ст. 2 Закона об адвокатуре, определил право адвоката РФ представлять интересы доверителя в органах государственной власти, судах и правоохранительных органах иностранных государств, международных судебных органах, негосударственных органах иностранных государств, если иное не установлено законодательством иностранных государств, уставными документами международных судебных органов и иных международных организаций или международными договорами РФ.

Не добавляет правовой логики в обсуждаемую проблематику, например, тот факт, что в соответствии с Законом об адвокатуре, гражданин иностранного государства, не являющийся адвокатом, изначально может, получив соответствующее образование на территории РФ и выполнив ряд предусмотренных законодательством условий, претендовать на получение статуса адвоката РФ и, в случае приобретения такового, осуществлять адвокатскую деятельность на территории РФ без каких-либо ограничений.

Видится необходимым, руководствуясь принципом взаимности, устранение противоречивости в части деятельности адвоката иностранного государства на территории РФ, деятельности адвоката РФ на территории иностранного государства, получении статуса адвоката РФ гражданином иностранного государства посредством внесения изменений и приведения во взаимное соответствие законодательства РФ, касающегося адвокатской деятельности, а также, возможно, внедрения практики заключения соответствующих международных договоров. [4]

Представление адвокатом иностранного государства интересов доверителей лишь по вопросам права своего государства не сможет обеспечить в полной мере защиты их прав и свобод, которыми они безусловно обладают на территории РФ, несмотря на то что не являются ее гражданами. Выбор в качестве представителя 
в судебном процессе иностранного адвоката является частью соблюдения законных прав и свобод лиц, в частности, реализации их права воспользоваться услугами конкретного представителя иностранного адвокатского сообщества. Следует также обратить внимание на то, что при определенных обстоятельствах не исключена ситуация, когда гражданин РФ, являющийся участником судебного процесса, пожелает реализовать свое право на защиту путем выбора в качестве представителя иностранного адвоката. Отсутствие в действующем законодательстве соответствующих правовых норм, равно как и противоречие между имеющимися законодательными актами в такой ситуации может явиться возможной причиной нарушенных прав.

Если обратиться к анализу вопросов, связанных с адвокатами - иностранцами, который представлен в статье А.М. Резепкина, мы можем увидеть, что автором выделено три следующих понятия: иностранный гражданин, получивший статус адвоката, адвокат иностранного государства, адвокат иностранного государства, который желает приобрести статус российского адвоката. [5]

В этой связи важно обратить внимание на полномочия адвоката иностранного государства, который по тем или иным причинам не получил статус российского адвоката (не прошел компетентностное подтверждение). Необходимо понимать, что право быть адвокатом представитель иностранного сообщества уже заслужил и, возможно, счел для себя правильным не доказывать этот факт, пусть даже и за пределами страны, гражданином которой он является и где был получен статус адвоката. Исходя из имеющихся разъяснений положений Закона об адвокатуре в части полномочий иностранного государства, мы можем заключить, что без подтверждения компетенций, иностранный адвокат лишен права участвовать в российском судебном процессе, что является прямым нарушением прав, как самого адвоката, так и лиц, которые желают воспользоваться услугами конкретного представителя иностранного адвокатского сообщества. Учитывая положения вышеуказанного закона, процедура сдачи экзамена не является сиюминутной и может занимать какое-то время, а помощь адвоката зачастую требуется незамедлительно,

Не лишним представляется обратить внимание на уже имеющейся опыт иностранных государств в этом вопросе. Так, в Германии, иностранный адвокат имеет возможность участвовать в судебном процессе, но совместно с адвокатом-представителем немецкого адвокатского сообщества.[5] Использование подобного опыта позволило бы, в частности, избежать необходимости применения достаточно сложной и затратной с точки зрения времени процедуры приобретения иностран- ным адвокатом необходимого статуса и позволило иностранному адвокату получить право на участие в судебном процессе.

Также считаем необходимым предоставление иностранными государствами на уровне взаимодействия административных органов адвокатских сообществ сведений об адвокатах иностранных государств для того, чтобы при занесении таких адвокатов в реестр, у российских властей была возможность проверки актуальности их статуса адвоката.

Вместе с тем, считаем, что защита прав участников правоотношений и споров по делам, представляющим государственную тайну, в этой части должны осуществляться с участием только российских адвокатов граждан Российской Федерации.

В 2017 году были разработаны поправки в Закон об адвокатуре и адвокатской деятельности, которые должны были дать необходимые полномочия Правительству РФ по установлению порядка деятельности иностранных адвокатов в России. Однако на настоящий момент времени поправки не утверждены.

Полагаем, что необходимо срочное законодательное урегулирование вопроса прав и полномочий иностранных адвокатов на территории Российской Федерации, в том числе с регламентацией участия представителей иностранного адвокатского сообщества в российском правосудии.

Учитывая тот факт, что Россия является огромной страной с массой возможностей и постоянно находящаяся в процессе международного сотрудничества, правовые вопросы с иностранными правовыми субъектами в рамках правовых отношений возникают крайне часто. Это, в свою очередь, означает, что представители иностранных адвокатур все чаще и чаще будут обращаться с ходатайствами о предоставлении права представлять интересы своих клиентов на территории РФ. Следовательно, правовую позицию по данному вопросу необходимо привести в соответствие во всех законодательных актах, поскольку это будет иной качественный уровень, который даст возможность, как представителям российского адвокатского сообщества, так и их иностранным коллегам четко понимать пределы полномочий прав, а также правовые возможности участия в российской системе права. Это, в свою очередь, даст российской правовой системе качественную оценку со стороны международного юридического сообщества и позволит вывести защиту прав и интересов граждан РФ, граждан иностранных государств и лиц без гражданства на новый уровень правового развития. 
ЛИТЕРАТУРА

1. Конституция Российской Федерации (принята всенародным голосованием 12 декабря 1993 года) // Российская газета. № 237 25.12.1993 г.

2. Федеральный Закон от 31.05.2002 № 63 - Ф3 «0б адвокатской деятельности и адвокатуре в Российской Федерации (в ред. от 29.07.2017) // Российская газета. № 100 05.06.2002.

3. Приказ Минюста РФ от 31 июля 2012 г. N151 «0б утверждении Административного регламента предоставления Министерством юстиции Российской Федерации государственной услуги по ведению реестра адвокатов иностранных государств, осуществляющих адвокатскую деятельность на территории Российской Федерации» // «Российская газета» № 192 от 22 августа 2012 г.

4. Определение ВС РФ от 10 февраля 2014 г. № 14-АПУ14-3 // СПС Гарант

5. Резепкин А.М. Адвокат иностранного государства в РФ // Право и государство: теория и практика, № 5, 2020 г. стр. 178-182

○ Рябова Ольга Алексеевна ( frau.lelya2012@yandex.ru ), Кузнецова Наталья Владимировна ( kuznezova-1963@mail.ru ).

Журнал «Современная наука: актуальные проблемы теории и практики»

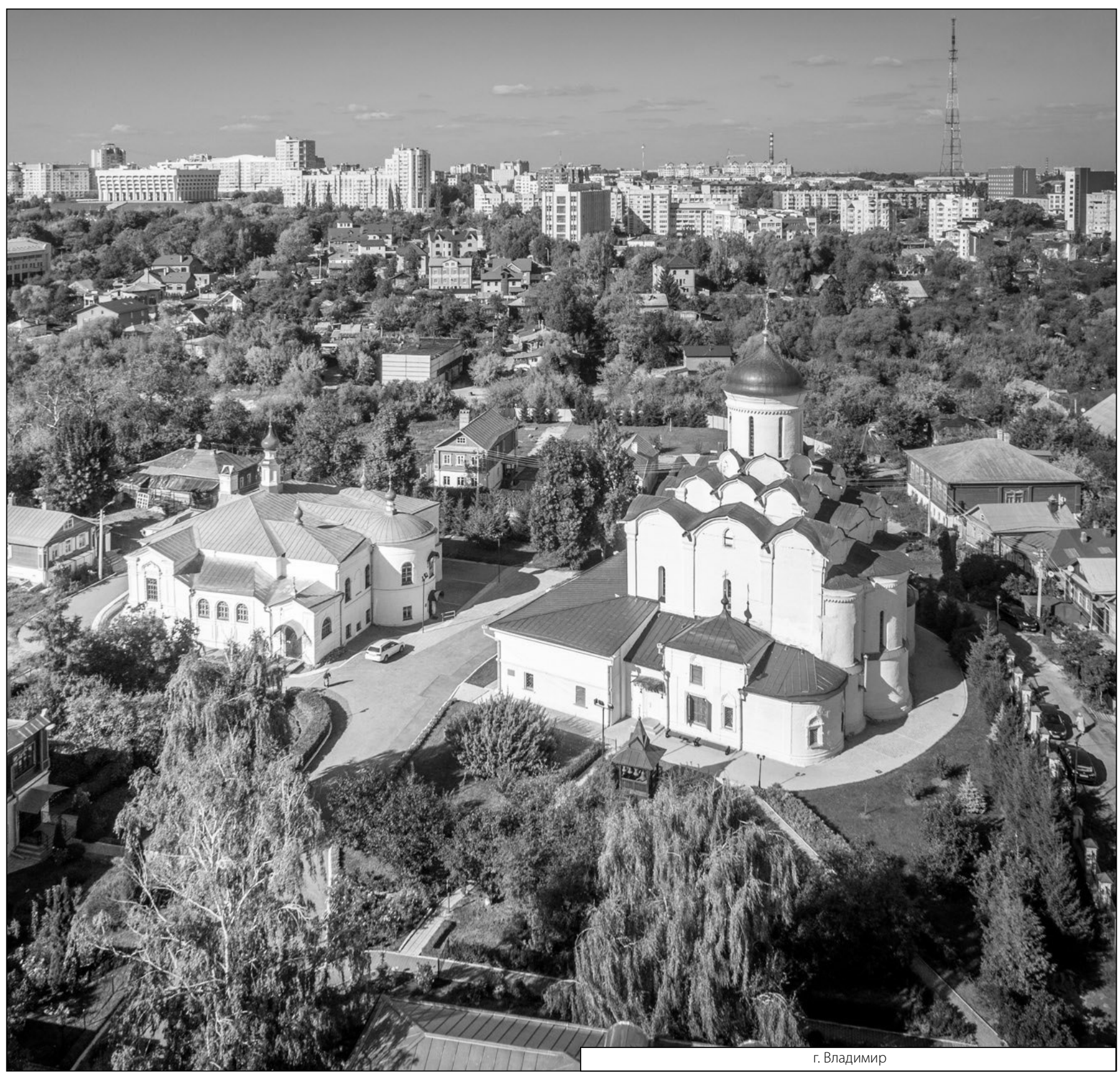

